\title{
The A-G polymorphism in exon 1 of the $C T L A-4$ gene is not associated with systemic lupus erythematosus
}

Joanne Heward, Caroline Gordon, Amit Allahabadia, Anthony H Barnett, Jayne A Franklyn, Stephen C L Gough

\begin{abstract}
Objectives-Factors contributing to the development of systemic lupus erythematosus (SLE) remain largely unknown although are likely to include both environmental and genetic components. Studies on murine lupus have indicated a role for an antibody that blocks binding of cytotoxic $\mathbf{T}$ lymphocyte associated-4 (CTLA-4) to B7 on antigen presenting cells in the treatment of disease, suggesting that CTLA-4 may play an important part in the disease process. This study, therefore, investigated the frequency of a previously described A-G polymorphism in exon 1 of the $C T L A-4$ gene, the $G$ allele of which has shown to be associated with both Graves' disease and type I diabetes, to determine whether this polymorphism was playing a part in the development of SLE.

Methods-One hundred and twenty six SLE patients and 363 control subjects were genotyped for the A-G polymorphism in exon 1 of the CTLA-4 gene. Target DNA was amplified using the polymerase chain reaction and the resulting product was digested using the BbvI restriction enzyme. Results-No differences in allele or genotype frequencies were observed between patients with SLE and control subjects. Conclusion-These data suggest that the A-G polymorphism in exon 1 of the $C T L A-4$ gene does not play a part in the genetic susceptibility to the development of SLE.
\end{abstract}

(Ann Rheum Dis 1999;58:193-195)

Systemic lupus erythematosus (SLE) is a multisystem disorder characterised by the presence of many antibodies. The aetiology of the disease is unknown but is thought to be caused by both genetic and environmental factors. SLE can occur at any age, and although $10-12 \%$ of patients have first degree relatives with the disease, ${ }^{1}$ the affected family members may present at similar time points suggesting the involvement of external environmental stimuli. $^{2}$ Despite this, the involvement of genetic components is still highly probable with concordance rates in monozygotic twins of between 24 and $69 \%$ compared with 2-9\% in dizygotic twins. ${ }^{3}$ Genetic studies in SLE have suggested roles for the MHC class II region (HLA) on chromosome $6 \mathrm{p},{ }^{4}$ the heat shock protein genes, ${ }^{5}$ and the tumour necrosis factor gene. ${ }^{6}$ However, the latter two may only be associated with disease on certain HLA haplotypes and the HLA region itself seems to be highly associated with the production of autoantibodies rather than with the disease itself, leaving the primary genetic components of SLE to be determined.

Studies of SLE in both humans and mice have shown that the production of autoantibodies by $\mathrm{B}$ cells is dependent upon stimulation from CD4+ $\mathrm{T}$ cells. ${ }^{78}$ Consequently any molecules that play a part in the interaction of $\mathrm{B}$ and $\mathrm{T}$ cells could be involved in the disease process. Cytotoxic $\mathrm{T}$ lymphocyte associated- 4 (CTLA-4) is involved in the regulation of $\mathrm{T}$ cells and is a member of the same family of cell surface molecules as CD28. Both of these molecules bind to B7 on $\mathrm{B}$ cells and the CTLA4-B7 complex can compete with the CD28/B7 complex and deliver negative signals to the $\mathrm{T}$ cell affecting $\mathrm{T}$ cell proliferation, cytokine production, and immune responses. ${ }^{9}$ After the observation that selective inhibition of B7-CTLA-4 interaction can produce antispecific $\mathrm{T}$ cell unresponsiveness in vitro and suppress immune function in vivo, experiments were performed to determine whether selective inhibition of B7-CTLA-4 interaction could suppress spontaneous autoimmune disease. Lupus prone NZB/NZW F1 mice were treated with a murine CTLA-4 immunoglobulin (muCTLA-4Ig), which blocked autoantibody production and prolonged life even when treatment was delayed until after the onset of clinical disease. ${ }^{10}$

The CTLA-4 gene is located on chromosome 2 q33 and was initially investigated as a candidate for autoimmune thyroid disease. Subsequently an AT repeat microsatellite in the 3' untranslated region of exon 3 and a threonine to alanine (A-G) polymorphism at position 49 in exon 1 , have been reported to be associated with both Graves' disease and type I diabetes. ${ }^{11}$ The aim, therefore, of this study was to investigate the frequency of the A-G polymorphism of the $C T L A-4$ gene in a population based case-control study to determine whether the CTLA-4 gene plays a part in genetic susceptibility to SLE.

\section{Methods}

PATIENTS

One hundred and twenty six white patients were recruited from the SLE clinic in the Rheumatology Department of the Queen Elizabeth Hospital and University of Birmingham, Birmingham. The patients fulfilled the American College of Rheumatology criteria for 
Table 1 Allele and genotype frequencies of the A-G polymorphism of the CTLA-4 gene in SLE patients and control subjects

\begin{tabular}{lclccl}
\hline & $\begin{array}{l}\text { G allele } \\
(\%)\end{array}$ & $\begin{array}{l}\text { A allele } \\
(\%)\end{array}$ & $\begin{array}{l}\text { AA genotype } \\
(\%)\end{array}$ & $\begin{array}{l}\text { AG genotype } \\
(\%)\end{array}$ & $\begin{array}{l}\text { GG genotype } \\
(\%)\end{array}$ \\
\hline SLE (n=126) & $82(33)$ & $170(67)$ & $54(43)$ & $58(46)$ & $14(11)$ \\
Controls $(\mathrm{n}=363)$ & $228(32)$ & $498(68)$ & $164(45)$ & $171(47)$ & $28(8)$ \\
\hline
\end{tabular}

A $v \mathrm{G}, \chi^{2}=0.099, \mathrm{p}=\mathrm{NS}$. AA $v$ AG $v \mathrm{GG}, \chi^{2}=1.39, \mathrm{p}=\mathrm{NS}$.

the classification of SLE. ${ }^{12}$ Blood was obtained from 363 ethnically matched control subjects with no history of autoimmune disease at various sites including the Blood Transfusion Service, Birmingham Heartlands Hospital and the Queen Elizabeth Hospital, Birmingham.

The study was approved by the local ethics committee and all subjects gave informed, written consent.

GENOTYPING AND STATISTICAL ANALYSIS

Genomic DNA was extracted from $10 \mathrm{ml}$ of blood using the Bacc II DNA extraction kit from Nucleon Biosciences. Amplification of the target DNA in exon 1 of the CTLA-4 gene was carried out by the polymerase chain reaction (PCR) using primers:- 5' GTC AAG GGA CCA TTA GAA G 3' and 5' CTT TGC AGA AGA CAG GGA TGA A 3' under appropriate reaction conditions. The resulting product was then subjected to restriction fragment length polymorphism (RFLP) analysis with the enzyme BbvI and the digestion products were termed A and G. To verify that complete digestion had occurred, selected samples were subjected to sequencing analysis using the ABI Prism 377 from Applied Biosystems.

Statistical analysis of results was performed using the $\chi^{2}$ test. A p value of less than 0.05 was considered to be significant.

\section{Results}

Samples from 126 SLE patients and 363 control subjects were successfully genotyped for the A-G polymorphism in exon 1 of the $C T L A-4$ gene. Table 1 summarises the results obtained from the study. Similar allele and genotype frequencies were observed in both the SLE patients and control subjects. Sequencing data verified alleles found by RFLP analysis.

\section{Discussion}

The A-G polymorphism at position 49 in exon 1 of the CTLA-4 gene encodes a threonine to alanine substitution in the leader peptide. The $\mathrm{G}$ allele (encoding alanine) has been shown to be associated with both Graves' disease and type I diabetes. ${ }^{11}$

A recent report on murine lupus suggests that treatment of the disease with a muCTLA4Ig blocks autoantibody production and prolongs life even in animals in advanced stages of clinical illness. ${ }^{10}$ This suggests that CTLA-4 is playing a part in the disease process at an immunological level - a hypothesis supported by the finding that the production of autoantibodies by $\mathrm{B}$ cells is dependent on stimulation from CD $4+\mathrm{T}$ cells, ${ }^{78}$ on which CTLA-4 is expressed. This finding has important implications for the treatment of human lupus as there is $76 \%$ homology between murine and human CTLA-4 with complete conservation in the cytoplasmic domain ${ }^{13}$ suggesting that this domain may be important in CTLA-4 function in both species. The mechanism by which muCTLA-4Ig suppresses murine lupus is as yet unknown although several hypotheses have been suggested. It may bind to B7 on B cells and prevent binding of CD28 thus inhibiting $\mathrm{T}$ cell activation ${ }^{10}$ or it may block the interaction of CTLA-4 and B7. ${ }^{14}$ Alternatively, instead of exerting an effect on $\mathrm{T}$ cell function, it may act directly on $\mathrm{B}$ cells and inhibit autoantibody production by depleting activated $\mathrm{B}$ cells. There is however no evidence to support this hypothesis. ${ }^{10}$

Although the A-G polymorphism of the $C T L A-4$ gene is associated with Graves' disease and type I diabetes, we found no association with SLE. This finding is in correlation with a recent study ${ }^{15}$ that found no association of the (AT) $n$ microsatellite, found in exon 3 of the $C T L A-4$ gene and in linkage disequilibrium with the A-G polymorphism, with SLE. Lack of association of the A-G polymorphism with SLE may be explained by the polymorphism not being in linkage disequilibrium with a predisposing allele of a disease causing mutation in SLE - a possibility as the threonine to alanine substitution is not expected to affect the function of the leader peptide or simply because the $C T L A-4$ gene polymorphism is not sufficient to influence disease expression in SLE. However, it seems more likely that the CTLA -4 gene itself is not involved in development of this disease and that the role of CTLA-4 is purely as an immunological molecule.

In conclusion, lack of association of the A-G polymorphism with SLE indicates that this region of the $C T L A-4$ gene is neither a disease causing mutation nor is it in linkage disequilibrium with such a mutation in SLE patients, in contrast with Graves' disease and type I diabetes.

This work was supported by a project grant from the Wellcome Trust (grant number M/953717), Eli Lilly UK and Lupus UK. AA is a Smith and Nephew Foundation Research Fellow.

1 Hochberg MC. The application of genetic epidemiology to systemic lupus erythematosus. J Rheumatol 1987;14:867-9. 2 Kaplan D. The onset of disease in twins and siblings with systemic lupus erythematosus. J Rheumatol 1984;11:64852.

3 Deapen DM, Escalante A, Weinrib L, Horwitz D, Bachman $\mathrm{B}$, Roy-Burman $\mathrm{P}$, et al. A revised estimate of twin concordance in systemic lupus erythematosus. Arthritis Rheum 1992;35:311-18.

4 Hamilton RG, Harley JB, Bias WB, Roebber M, Reichlin M, Hochberg MC, et al. Two Ro (SS-A) autoantibody responses in systemic lupus erythematosus: correlation of responses in systemic lupus erythematosus: correlation of Ro (SS-A) autoantibody. Arthritis Rheum 1988;31:496Ro 505.

5 Jarjour W, Reed AM, Gauthier J, Hunt S, Winfield JB. The 8.5-kb Pst I allele of the stress protein gene, Hsp 70-2. An independent risk factor for systemic lupus erythematosus in African Americans. Hum Immunol 1996;45:59-63.

6 Wilson AG, Gordon C, di Giovine FS, de Vries N, van de Putte LB, Emery P, et al. A genetic association between systemic lupus erythematosus and tumour necrosis factor alpha. Eur J Immunol 1994;24:191-5.

7 Steinberg AD, Gourlet MF, Klinman DM, Tsokos GC, Scott DE, Krieg AM. Systemic lupus erythematosus. Ann Intern Med 1991;115:548-59.

8 Wofsy D, Seaman WE. Successful treatment of autoimmunity in NZB/NZW F1 mice with monoclonal antibody to L3T4. J Exp Med 1985;161:378-91.

9 Bluestone JA. Is CTLA-4 a master switch for peripheral T cell tolerance? J Immunol 1997;128:1989-93.

10 Finck BK, Linsley PS, Wofsy D. Treatment of murine lupus with CTLA4Ig. Science 1994;265:1225-7. 
11 Donner H, Rau H, Walfish PG, Braun J, Siegmund T, Finke $\mathrm{R}$, et al. CTLA4 alanine- 17 confers genetic susceptibility to Graves' disease and to type I diab
Endocrinol Metab 1997;82:143-6.

12 Tan EG, Cohen AS, Fries JF, Masi AT, McShane DJ, RothTan EG, Cohen AS, Fries JF, Masi AT, McShane DJ, Roth-
field NF, et al. The 1982 revised criteria for the classification of systemic lupus erythematosus. Arthritis Rheum 1982;25:1271-7.

13 Dariavich P, Mattéi M-G, Golstein P, Lefranc M-P. Human Ig superfamily CTLA-4 gene: chromosomal localization and identity of protein seqeunce between murine and human CTLA-4 cytoplsmic domains. Eur J Immunol 1988;18:1901-5.

14 Hathcock KS, Laszlo G, Dickler HB, Bradshaw J, Linsley P, Hodes RJ. Identification of an alternative CTLA-4 ligand costimulatory for $\mathrm{T}$ cell activation. Science 1993;262: 905-7.

15 Mehrian R, Quismorio FP, Strassmann G, Stimmler MM, Horwitz DA, Kitridou RC, et al. Synergistic effect between $I L-10$ and $b c l-2$ genotypes in determining susceptibility to systemic lupus erythematosus. Arthritis Rheum 1998;41: $596-602$.

\section{Annals of the Rheumatic Diseases - http://www.annrheumdis.com}

Visitors to the world wide web can now access Annals of the Rheumatic Diseases either through the BMJ Publishing Group's home page (http://www.bmjpg.com) or directly by using its individual URL (http:// www.annrheumdis.com). There they will find the following:

- Current contents list for the journal

- Contents lists of previous issues

- Members of the editorial board

- Subscribers' information

- Instructions for authors

- Details of reprint services

A hotlink gives access to:

- BMJ Publishing Group home page

- British Medical Association web site

- Online books catalogue

- BMJ Publishing Group books

The web site is at a preliminary stage and there are plans to develop it into a more sophisticated site. Suggestions from visitors about features they would like to see are welcomed. They can be left via the opening page of the BMJ Publishing Group site or, alternatively, via the journal page, through "about this site". 